\title{
Observations on incidental catch of cetaceans in three landing centres along the Indian coast
}

K.S.S.M.Yousuf*‡, A.K. Anoop*, B. Anoop*,V.V. Afsal*, E.Vivekanandan*, R.P. Kumarran ${ }^{\dagger}$, M. Rajagopalan*, P.K. Krishnakumar* and P. Jayasankar*

*Central Marine Fisheries Research Institute, Cochin 6820I8, India. ${ }^{\dagger}$ AP 454, 22nd Street Thiruvalluvar Kudiyiruppu Anna Nagar, Chennai 600040 , India. ${ }^{\circ}$ Corresponding author, e.mail:yusuf_vizag@hotmail.com

\begin{abstract}
A short term survey to quantify the number of marine mammals incidentally caught, and interviews to gain perceptions of local fishers towards issues of by-catch, were conducted.A total of 44 cetaceans were recorded as incidental catches at Chennai, Kakinada and Mangalore fishing harbours during 80 days of observation. Six species of dolphins and one species of porpoise were recorded.The spinner dolphin Stenella longirostris was the most frequently caught (38.6\%), followed by the finless porpoise Neophocaena phocaenoides (31.8\%). Gillnets and purse seines operated from motorised boats accounted for the entire by-catch. It is estimated that 9000-10,000 cetaceans are killed by gillnets every year along the Indian coast. The intricacies and possibilities of reducing cetacean kills by gillnets are discussed in the paper.
\end{abstract}

\section{INTRODUCTION}

Marine mammal capture, both incidental and intentional, is a matter of concern world wide. Marine mammal mortality due to fishing operations is identified as one of the major threats to the viability of local and regional populations throughout the range of a species (Northridge \& Pilleri, 1986). At the same time, the marine mammal-fishery interactions cause a loss in revenue to small and large scale fishermen by way of mechanical damage to gear and to a certain extent loss of captured fish. Among several gears, gillnets and purse seines have been identified as the main cause for marine mammal mortality at the global scale (Cockcroft \& Krohn, 1994; Perrin et al., 1994; Archer et al., 200I;Wise et al., 200I; Read et al., 2006).

India with its vast coastline and associated fishery industry, both artisanal and mechanized, is a source of huge marine incidental catch ranging from threatened species of mollusks and fish to endangered turtles, sea snakes and marine mammals. The literature on incidental catch of cetaceans reported in India is vast (Lal Mohan, 1985; Mahadevan et al., 1990; Kasim et al., 1993; Satya Rao \& Chandrasekar, 1994; Thiagarajan et al., 2000). According to Lal Mohan (1994), the annual cetacean mortality caused by the Indian gill net fishery is 1000-1500. Entanglement of cetaceans in other fishing gears such as trawls, purse seines, shore seines and long-lines has also been reported. While the Indian Wildlife Protection Act of 1972 puts all marine mammals in Schedule I of the Act, very little has been done in ways to mitigate mortality. It is imperative to initiate a systematic by-catch assessment program by monitoring of fish landing sites. At the same time, it is important to identify the reasons that lead to by-catch so as to find ways to reduce or mitigate marine mammal mortality.

Here we sampled three selected fish landing centres along the south-east coast of India. We used short-term surveys to quantify the number of marine mammals incidentally caught and interviews to gain perceptions of local fishers towards issues of by-catch, by-catch utility and conservation of marine species.

\section{MATERIALS AND METHODS}

Direct observations were made in three major fishing harbours: Chennai Fisheries harbour $\left(13^{\circ} 05^{\prime} \mathrm{N} 79^{\circ} 46^{\prime} \mathrm{E}\right)$ for 20 days during September-October 2004; Kakinada Fisheries harbour (16 $\left.5 \mathrm{I}^{\circ} \mathrm{N} 80^{\circ} \mathrm{I} 0^{\prime} \mathrm{E}\right)$ in March, May and September 2004 for 15 days in each month; and Mangalore Fisheries harbour $\left(12^{\circ} 5 \mathrm{I} N \mathrm{~N}, 74^{\circ} 49^{\prime} \mathrm{E}\right)$ for 15 days during November-December 2005 (Figure I). The observations were made between 0600 and 0900 hours. Basic data for each animal (species, sex and morphometric measurements wherever possible) along with the type of craft and gear that landed the catch were recorded.

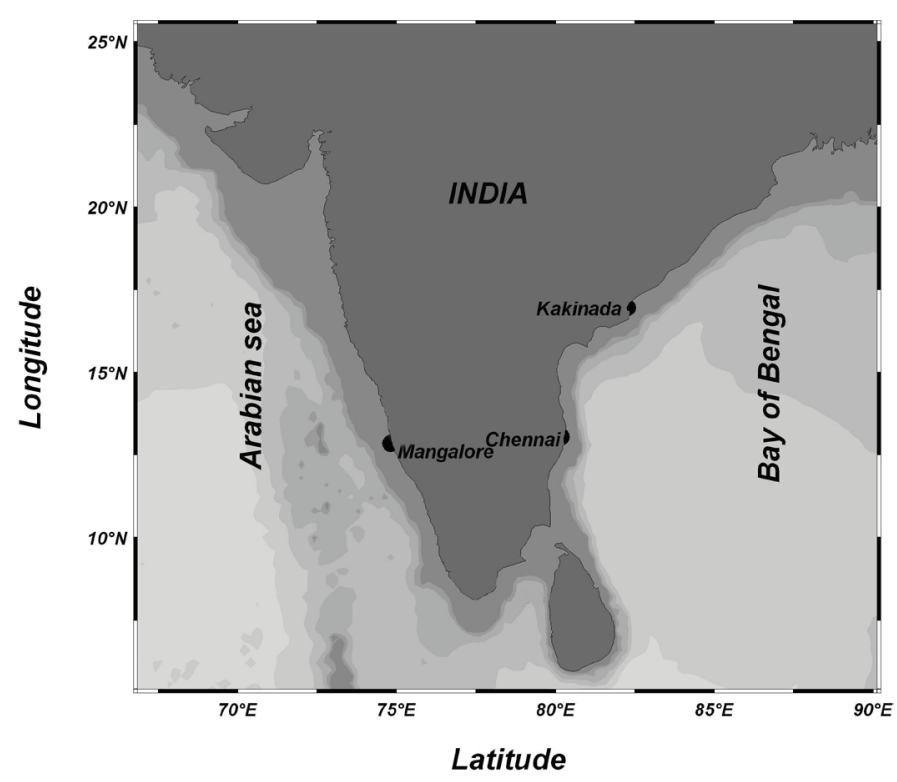

Figure I. Map of India showing the centers where the cetaceans were landed. 
Table I. Details of cetaceans caught by fishing during the study period.

\begin{tabular}{|c|c|c|c|c|c|c|c|c|}
\hline \multirow[t]{2}{*}{ S. No. } & \multirow[t]{2}{*}{ Species } & \multirow[t]{2}{*}{ Location } & \multicolumn{2}{|c|}{ No of animals } & \multirow{2}{*}{$\begin{array}{l}\text { Body length } \\
(\mathrm{cm})\end{array}$} & \multirow{2}{*}{ Weight (kg) } & \multirow{2}{*}{$\begin{array}{l}\text { Month and year } \\
\text { caught }\end{array}$} & \multirow[t]{2}{*}{ Gear } \\
\hline & & & Male & Female & & & & \\
\hline I & Stenella longirostris & Chennai & 9 & 3 & $84-170$ & $6-47$ & Sep/Oct-04 & Gillnet \\
\hline 2 & Stenella longirostris & Kakinada & I & 3 & $130-168$ & - & Sep-04 & Gillnet \\
\hline 3 & Stenella longirostris & Mangalore & 1 & - & 139.5 & 24 & Sep-04 & Gillnet \\
\hline 4 & Stenella attenuata & Chennai & 1 & - & 93 & 8 & Oct-04 & Gillnet \\
\hline 5 & Tursiops aduncus & Chennai & 2 & - & $140-153$ & $34.7-36.2$ & Oct-04 & Gillnet \\
\hline 6 & Tursiops aduncus & Kakinada & - & 1 & 227 & - & Mar-04 & Gillnet \\
\hline 7 & Delphinus capensis & Kakinada & - & 2 & $165-175$ & - & May-04 & Gillnet \\
\hline 8 & Delphinus capensis & Mangalore & - & 1 & 190 & - & Feb-06 & Gillnet \\
\hline 9 & Sousa chinensis & Mangalore & I & 1 & 179-273.5 & 54-100 approx & Nov/Dec-05 & Gillnet \\
\hline 10 & Sousa chinensis & Chennai & 2 & - & $192-195$ & $59-60$ & Oct-04 & Gillnet \\
\hline 11 & Grampus griseus & Chennai & 1 & 1 & $|74-24|$ & $54-129$ & Sep/Oct-04 & Gillnet \\
\hline 12 & Neophocaena phocaenoides & Mangalore & 8 & 6 & $95-149$ & $14-57$ & Nov-05 & Purse seine \\
\hline
\end{tabular}

Interviews with fishermen were conducted to collect information regarding knowledge and perceptions that fishermen hold regarding marine mammals. For this purpose, a questionnaire designed to extract information known to fishermen on cetaceans and their interactions with fisheries was used (Appendix I). A total of 60 fishermen were asked questions pertaining to their fishing effort and marine mammal sightings, strandings, hunting, incidental catches, and their beliefs and myths toward the animals.

\section{RESULTS}

A total of 44 cetaceans were recorded as incidental catch from the 3 centres during the survey period (Table I). Seven species of cetaceans were recorded: spinner dolphin (Stenella longirostris), finless porpoise (Neophocaena phocaenoides), Indo-Pacific bottlenose dolphin (Tursiops aduncus), pantropical spotted dolphin (Stenella attenuata), Risso's dolphin (Grampus griseus), Indo-Pacific humpback dolphin (Sousa chinensis), and long-beaked common dolphin (Delphinus capensis). The spinner dolphin was the species most commonly caught (38.6\%) followed by the finless porpoise (31.8\%) (Figure 2). The catch landed at Chennai consisted of 5 species: S. longirostris, T. aduncus, S. chinensis, S. attenuata and G. griseus. At Mangalore, the catch was comprised mostly of $N$. phocaenoides, with some Delphinus capensis, S. longirostris and S. chinensis. Three species (S. longirostris, D. capensis and T. aduncus) were recorded at Kakinada. In descending order of frequency of by-catch, the order was as follows: S. longirostris, N. phocaenoides, T. aduncus, S. chinensis, D. capensis, G. griseus and S. attenuata.

The length of S. longirostris ranged from 84 to $170 \mathrm{~cm}$ and that of $N$. phocaenoides from 95 to $149 \mathrm{~cm}$. The modal length groups for S. longirostris were $80-100 \mathrm{~cm}$ and $160-180 \mathrm{~cm}$ (Figure 3 ) and for $N$. phocaenoides $140-160 \mathrm{~cm}$ (Figure. 4). Juveniles measuring $<100 \mathrm{~cm}$ were also caught.

\section{Fisheries and fishing gear}

Of the 44 incidentally caught cetaceans, 30 were taken in gillnets and 14 by purse seines, both operated from motorized boats. The purse-seine operation targeted the oil sardine (Sardinella longiceps) and was operated at 5-8m depth at midnight very close to the shore. The mesh size ranged from

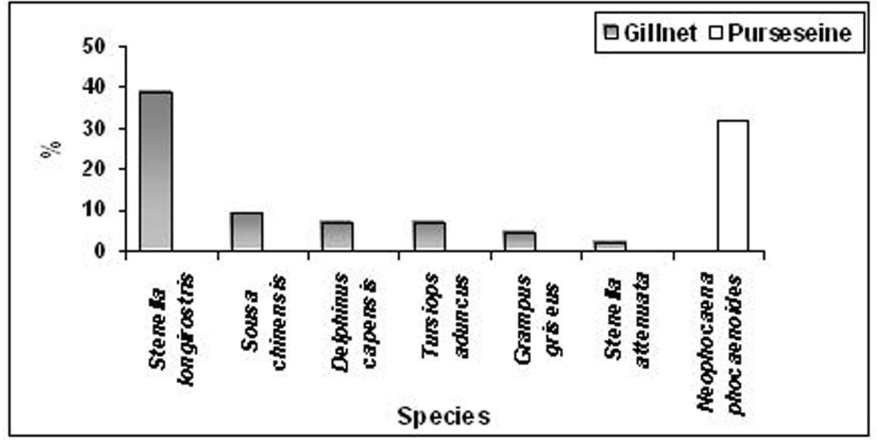

Figure 2. Ratios of species bycaught in fishing gear and landed at the three surveyd centres.

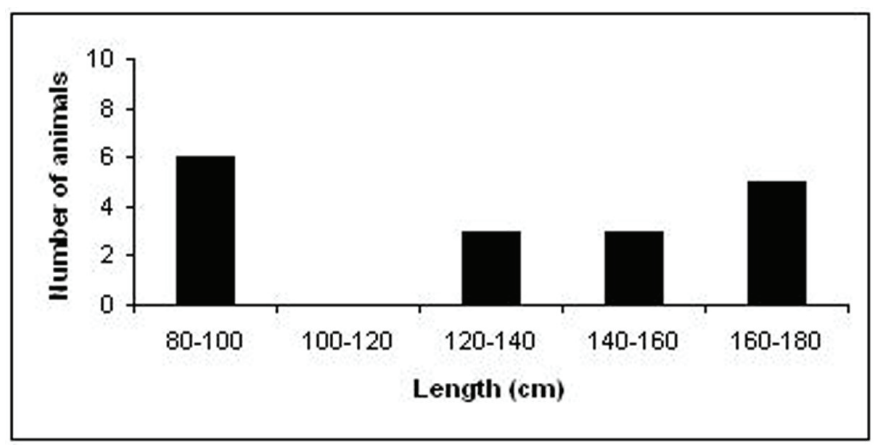

Figure 3. Length frequency of Stenella longirostris caught by gillnet $(\mathrm{N}=17)$.

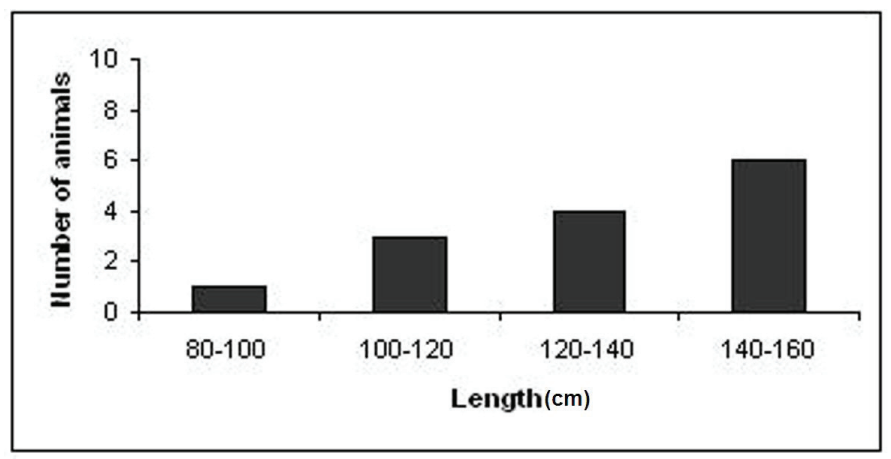

Figure 4. Length-frequency of Neophocaena phocaenoides caught by purse seine $(N=14)$. 
Table 2. Specification of craft and gear operations in which cetacean were incidentally caught.

\begin{tabular}{|c|c|c|c|}
\hline Parameters & Kakinada & Chennai & Mangalore \\
\hline Type of boat & Mechanised & Mechanised & Mechanised \\
\hline Length of boat (m) & 9 & $10-15$ & $10-15$ \\
\hline Engine power (hp) & $20-30$ & $50-108$ & $50-100$ \\
\hline Area of operation & $\begin{array}{c}\text { Off Kakinada, } \\
\text { Upada, Bhiravampalam }\end{array}$ & $\begin{array}{c}\text { north \& south of Chennai, } \\
\text { Nizampatanam }\end{array}$ & Off Mangalore \\
\hline $\begin{array}{l}\text { Operating distance from } \\
\text { the shore }(\mathrm{km})\end{array}$ & $4-10$ & 20-70(multi day fishing) & Up to $50 \mathrm{~m}$ depth \\
\hline \multirow[t]{2}{*}{ Type of net operated } & $\begin{array}{l}\text { Mono filament \& multi filament } \\
\text { drift and bottom set gillnets }\end{array}$ & Drift gillnet (multi filament) & gillnet, purse seine \\
\hline & \multicolumn{2}{|c|}{ Specification of gillnet } & \\
\hline Mesh Size (cm) & $4-7$ & 6 & 2.5-7.5(gillnet) \\
\hline Height of gang (m) & 6 & $8-12$ & - \\
\hline Length of gang (m) & 50 & $100-240$ & - \\
\hline No of gangs & $20-30$ & $10-30$ & $4-7$ \\
\hline $\begin{array}{l}\text { Distance covered } \\
\text { by net }(\mathrm{km})\end{array}$ & $1-1.5$ & $1.0-6$ & $0.5-1.5$ \\
\hline Operational depth & $20-100$ & $30-200$ & $25-70$ \\
\hline No of days in fishing trip & 1 & $1-4$ & $\mathrm{I}-2$ \\
\hline No of hauls (per day) & 1 & 1 & 1 \\
\hline Soaking duration (h) & $4-6$ & $6-8$ & $6-10$ \\
\hline Time of soaking & evening & evening & morning and evening \\
\hline Targeted fish & seerfish, perches, & seerfish, shark, carangids, tuna & seerfish, sharks, carangids \\
\hline
\end{tabular}

I to $3 \mathrm{~cm}$; the height from 2 to $3 \mathrm{~m}$ and length from 180 to $270 \mathrm{~m}$. Purse seines operated off Mangalore commonly caught $N$. phocaenoides. Interviews with fishermen also confirmed higher cetacean entanglement in gillnets at all the landing centres. The gillnetters that took cetaceans as by-catch fished out 4 to $70 \mathrm{~km}$ from the shore with mesh size ranging from 4.0 to $7.5 \mathrm{~cm}$. The total length of gillnet ranged from 0.5 to $6 \mathrm{~km}$. The total number of gangs varied from 4 to 30 , with length of each gang from 50 to $240 \mathrm{~m}$ and height from 6 to $12 \mathrm{~m}$. These boats fished between evening and early hours in the morning with the maximum number of dolphin entanglements encountered in the pelagic fishery for yellowfin tuna (Thunnus albacares), sharks, and seerfish (Scomberomorus commerson and Scomberomorus guttatus).

The two species commonly involved in the gillnet fishery were S. longirostris and T. aduncus.

The overall size of motorized boats that incidentally caught dolphins and porpoises in the surveyed centres was 9 to $15 \mathrm{~m}$ (20 to $108 \mathrm{hp}$ engine) (Table 2).

\section{Responses by fishermen}

Of the 60 fishermen interviewed, $95 \%$ were aware that marine mammals were protected under law enforced by the State Forest Department. Some fishermen interviewed in Kakinada and Chennai informed us that the meat of incidentally caught dolphins was used as bait in the shark fishery, while others said they discarded the incidentally caught cetaceans while at sea. In case of animals that were found stranded or washed ashore, they reported the same to the local Forest Department officials. The fishermen at all three centres informed us that there was no deliberate catch of cetaceans. However, targeted fishing by purse seines for porpoises was reported off Mangalore. A few fishermen in Kakinada mentioned that consumption of dolphin meat is considered a good remedy for knee and back pain. About $85 \%$ of the respondents complained that while they carry out fishing, dolphins eat the fish caught in the net, causing damage to the gear.

\section{DISCUSSION}

Though the surveys of incidental catch were limited to a few landing centres for a short duration, they indicate the great vulnerability of cetaceans to fishing gear. In 80 days' observations in 3 centres, 44 incidentally caught cetaceans were recorded, i.e. one animal was recorded for about every two days. This is probably an underestimate, since the observations were restricted to only 3 hours in a day. Among the three centres, the highest cetacean by-catch was recorded at Mangalore ( 1.2 cetaceans per day of observation) followed by Chennai ( 1.0 per day) and Kakinada ( 0.2 per day). However, earlier incidental cetacean catch records (Nageswara Rao \& Venkataramana, 1994; Venkataramana \& Achaya, 1997; Thathaya \& Achaya, 1998) show that the gillnet fishery operated in and around Kakinada causes considerable mortality. 
Stenella longirostris was the most frequently caught species off Chennai in the gillnet fishery. This species has earlier been reported as by-catch in the gillnet fishery off Calicut (Lal Mohan, 1985). In the sighting cruises carried out onboard FORV SAGAR SAMPADA, the spinner dolphin was recorded as the most abundant species in the Indian EEZ (CMFRI, 2007). In the three surveyed centres, trawls were the most dominant gear with approximately 2500 active trawlers, compared to 400 motorised gillnetters and 50 purse-seiners. Purse seiners operate only from Mangalore. However, gillnetters accounted for $68.9 \%$ of the catch and purse seiners for the remaining. No cetacean catch was recorded in trawlers in the present study. Entanglement of T. aduncus in trawl nets has been earlier reported off Mandapam andVisakhapatnam (Pillai \& Kasinathan, 1987; Chandrasekar et al., 1993). Nevertheless, trawlers cause less mortality of marine mammals compared to gillnetters and purse-seiners. This could be explained by the disturbance caused by the trawling action at the bottom and at midwater warning cetaceans before they can get caught. In Mangalore, a large number of $N$. phocaenoides were incidentally caught by purse seines. Purse seining is known to be the main cause of dolphin mortality worldwide (Archer et al., 200I;Wise et al., 2007) but in India, the purse seine is not a predominant gear and is operated only along the coasts of Karnataka and Goa. By analysing the stomach contents of incidentally caught cetaceans, Anoop et al. (2007) concluded that finless porpoise are caught by purse seines when they move very close to the shore off Mangalore for feeding on oil sardine.

Maigret (1994) states that a dolphin's slower movement near the surface, less alertness and poor net detection capacity could be the reasons for high entanglement in gillnets. Waring et al. (1990) suggest that catch at night is due to nocturnal behaviour of prey that the cetaceans feed upon. In the present study, all the gillnet by-catch was from nets operated at night, which could be one of the reasons for low detectability. Thus the higher vulnerability of cetaceans to gillnet may be due to the large area covered by the net in the water column, and poor detection of the net by cetaceans.

The conflicts between gillnet fisheries and incidental capture of cetaceans is one between conservation of endangered animals and economic factors and livelihood of fishermen. The drift gillnets are popular among the fishermen, as they are effective in catching the target fish, namely seerfish, tunas and sharks. According to a marine fisheries census, 14, I83 motorized gillnetters are operating along the Indian coast (CMFRI, 2006). In recent years, the length of the gillnet has been increased and the fishing grounds have been extending to oceanic waters. The total number of dolphins killed by fishing operations in the Indian Seas must be quite substantial considering the extent of operation of these nets. Considering that 44 cetacean kills were recorded in 80 days by $\sim 400$ gillnetters, we could be looking at alarmingly high numbers of around 9000-10,000 cetaceans killed every year by 14, 183 motorised gill-netters in about 240 days of operation in the Indian waters. This could still be an under-estimate, as our observations were restricted to only 3 hours per day. This estimate is considerably higher than the estimates (1000-1500) by Lal Mohan (1994). Increase in the number and efficiency of gillnetters has perhaps increased mortality in the last 15 years. To arrive at a better estimate of marine mammal mortality along the Indian coast, it is important to undertake surveys covering more fish landing centres for longer duration.

In addition to humanitarian and ecological concern for dolphins, the killing of dolphins is detrimental to the fishermen. Dolphins are valuable to the fishermen because the presence of dolphins indicates presence of fish schools. Thus reducing dolphin kill as much as possible is in the interest of the fishermen themselves. If the fishermen are convinced about this, skillful fishermen will be able to effectively reduce the incidental capture and mortality of dolphins (NRC, 1992).

Trying to find approaches to better manage gill netting so that by-catch can be reduced is a difficult task. Fishing and fishing type are cultural aspects of identity. It is also difficult to find alternative cost-effective fishing methods as efficient as gillnetting. Perhaps reducing the set - time of the net may help in recovery and release of dolphins, but the fishermen find the job of setting nets labour intensive and thus prefer longer set times. However, as an incentive-based program, this method of mitigation could be approached. Avoiding areas and seasons of abundance of dolphins could be another method to effectively reduce mortality. However, without detailed information on distribution, abundance, core areas and habitat use for the different species, it is not yet possible to identify regions that could be assigned spatial or temporal protection.

Use of passive sonar and other acoustic instruments to recognize the presence of dolphins could also reduce the incidental kill (NRC, 1992) by informing fishers of their presence. Attaching pingers to the gillnets to scare away the dolphins may be attempted, and is a very expensive option. Acoustic pingers are found to be effective for some species of (harbour) porpoise (Werner et al., 2006) and in the drift gillnet fishery, experimented off California (Barlow and Cameron, 2003). While excluder devices attached to trawl nets are found to be effective for reducing by-catch of dolphins and turtles (ICAR, 2005). Research needs to be conducted urgently to investigate possible by-catch reduction methods in India, bearing in mind that the methods used may have to be specially tailored for the region. Without such research, and swift implementation of effective by-catch reduction methods many local populations of marine mammal species could well face extirpation in India. 
We are thankful to the Director, CMFRI, Cochin for encouragement and for facilities. The authors thank Dr William Perrin and Ms Dipani Sutaria for critical review of the paper. We are grateful to anonymous referees for their valuable suggestions. It is a pleasure to express our gratitude to all the fishermen who provided information on cetaceans and their incidental catches. The funding by the Central Marine Living Resources \& Ecology, Ministry of Earth Sciences, Government of India, is greatly acknowledged.

\section{REFERENCES}

Anoop, A., Yousuf, K.S., Kumaran, PL., Nayak, H., Anoop, B., Afsal, V.V. \& Rajagopalan, M., Vivekanandan, E., Krishnakumar P.K and Jayasankar. P., 2008. Stomach content of cetaceans incidentally caught along Mangalore and Chennai coasts of India. Estuarine Coastal \& Shelf Science, 76, 909-913.

Archer, F., Gerrodette, T., Dizon, A., Abella, K. \& Southern. S., 200I. Unobserved kill of nursing dolphin calves in a tuna purse-seine fishery. Marine Mammal Science, 17, 540-554.

Barlow, J. \& Cameron. G.A., 2003. Field experiments show that acoustic pingers reduce marine mamma bycatch in the California drift gill net fishery. Marine Mammal Science, 19, 265-283.

Chandrasekar, M., Chittibabu, K., Achaya, P., Prabhakar, R.V.D. \& Viyayakumaran. K., 1993. On the landing of a young bottlenose dolphin at Visakhapatnam. Marine Fisheries Information Service, Technical \& Extension Series, 1 22, 24-25.

CMFRI, 2006. Marine Fisheries Census 2005, Part I. Kochi: Central Marine Fisheries Research Institute, pp. 104.

CMFRI, 2007. Studies on Marine Mammals of Indian EEZ and the Contiguous Seas. New Delhi: Central Marine Fisheries Research Institute, Final Report submitted to Ministry of Earth Sciences, I-2 I 2.

Cockcroft, V.G. \& Krohn. R., 1994. Passive gear fisheries of the southwestern Indian and southeastern Atlantic Oceans. An Assessment of their possible impact on cetaceans. In Gillnets and cetaceans (ed.W.F. Perrin et al.). Report of International Whaling Commission, Special Issue, 1 5, 317-328.

ICAR, 2005. An indigenous Turtle Excluder Device for protection of sea turtle. ICAR Newsletter, I I, I-3.

Kasim, H.M., Ameer Hamsa, K.M.S \& Balasubramanian, T.S., 1993. On an accidental landing of false killer whale, Pseudorca crassidens by drift gillnet off Veerpandianpatnam along Gulf of Mannar. Marine Fisheries Information Service, Technical \& Extension Series, $120,18-19$.

Lal Mohan, R.S., 1985. Observations on the by-catch of dolphins S. longirostris, T. aduncus, S. chinensis and D. delphis tropicalis in the gill nets off Calicut coast, India. In Proceedings of the Symposium on Endangered Marine Animals and Marine Parks, (ed. E.G. Silas), pp. 78-83. Marine Biological Association of India, 12-16 January 1985.

Lal Mohan, R.S., 1994. Review of gillnet fisheries and cetacean bycatches in the northeastern Indian Ocean. Reports of the International Whaling Commission Special Issue, I 5, 329-343.

Mahadevan Pillai, P.K \& Chandrangathan, S.B., 1990. On the driftnet entangled dolphins landed at Sakthikulangara. Marine Fisheries Information Service, Technical \& Extension Series, 1 04, I6-I7.

Maigret, J., 1994. Marine mammals and fisheries along the West African coast. Report of International Whaling Commission, Special Issue, 15, 307-317.

Nageswara Rao,T. \& Venkataramana, P., 1994. On the landing of bottlenose dolphin Tursiops truncatus at Kakinada. Marine Fisheries Information Service, Technical \& Extension Series, I 27, 16 pp.

Northridge, S. \& Pilleri, G., 1986. A review of human impact on small cetaceans. Investigations on Cetacea, I8, $22 I-26 I$.

NRC, (1992). Dolphins and the Tuna Industry. Washington, DC: National Research Council Report, National Academy Press, 169 pp.

Perrin,W.F., Donovan, G.P. \& Barlow, J., 1994. Gillnets and cetaceans. Report of International Whaling Commission Special Issue, 15, 629 pp.

Pillai, K.S. \& Kasinathan, C., 1987. Some observations on dolphin in Mandapam area with a note on their food. Marine Fisheries Information Service, Technical \& Extension Series, 7 I, I3-I6.

Read, A.J., Drinker, P. \& Northridge, S., 2006. Bycatch of marine mammals in U.S and global fisheries. Biological Conservation, 20, 163-169.

Satya Rao, S. \& Chandrasekar. S., 1994. On the landing of spinner dolphins Stenella longirostris at Lawson's bay, Visakhapatnam. Marine Fisheries Information Service, Technical \& Extension Series, I 27, 18.

Thathaya, E. \& Achayya. P., 1998. On the landing of dolphins at Dummulupetta, East Godavari district, Andhra Pradesh. Marine Fisheries Information Service, Technical \& Extension Series, 152, 17-18.

Thiagarajan, R. \& Krishnapillai. S., 2000. Accidental catch of three risso's dolphins at Beemapally, near Vizhinjam. Marine Fisheries Information Service, Technical \& Extension Series, 163, 10.

Venkataramana, P. \& Achayya, P., 1998. On the capture of a bottlenose dolphin off Kakinada. Marine Information Service Technical \& Extension Series, I55, 20.

Waring, G.T., Gerior, P., Payne, M.P., Parry, B.L. \& Nicolas, J.R., 1990. Incidental take of marine mammals in foreign fishery activities off the northeast United States, 1977-1988. Fisheries Bulletin, 88, 347-360.

Werner,T., Kraus, S., Read,A. \& Zollett, E., 2006. Fishing techniques to reduce the bycatch of threatened marine animals. Marine Technology Society Journal, 40, 50-68.

Wise, L., Silva, A., Ferreira, M., Silva, M. A. \& Sequeira, M., 200I. Interactions between small cetaceans and the purse-seine fishery in western Portuguese waters. Scientia Marina, 7 I, 405-4I 2.

Submitted 9 April 2008. Accepted 2 June 2008. 
Appendix I. Questionnaire.

Name of fisherman:
Type of boat:
Length of boat:
Power of Engine (hp):
Type of gear used:
Operating distance from the shore(km):
Area of operation:
Mesh size:
Height of the net:
No of gangs:
Distance covered by net:
Depth of net operated(m):
No of days involved in fishing:
No of hauls:
Soaking duration:
Time of soaking:
Fish composition( commonly caught by net):
Whether dolphin is targeted:
Whether dolphin comes as by catch:
If they see dolphin in sea what they do:
If they catch it what they do it:
Whether they are aware of forest law:

